\title{
Vitex agnus-castus L.: Main Features and Nutraceutical Perspectives
}

\author{
Eliana B. Souto ${ }^{1,2, *}$, Alessandra Durazzo ${ }^{3}\left(\mathbb{D}\right.$, Amirhossein Nazhand $^{4}$, Massimo Lucarini ${ }^{3}$, \\ Massimo Zaccardelli ${ }^{5}$, Selma B. Souto ${ }^{6}$, Amelia M. Silva ${ }^{7,8}$ (D), Patricia Severino 9,10,11(D), \\ Ettore Novellino ${ }^{12}$ and Antonello Santini ${ }^{12, * \text { (D) }}$
}

1 Department of Pharmaceutical Technology, Faculty of Pharmacy, University of Coimbra, Pólo das Ciências da Saúde, Azinhaga de Santa Comba, 3000-548 Coimbra, Portugal

2 CEB-Centre of Biological Engineering, University of Minho, Campus de Gualtar, 4710-057 Braga, Portugal

3 CREA-Research Centre for Food and Nutrition, Via Ardeatina 546, 00178 Roma, Italy; alessandra.durazzo@crea.gov.it (A.D.); massimo.lucarini@crea.gov.it (M.L.)

4 Department of Biotechnology, Sari Agricultural Science and Natural Resource University, 9th km of Farah Abad Road, Sari 48181 68984, Mazandaran, Iran; nazhand.ah@gmail.com

5 CREA-Research Centre for Vegetable and Ornamental Crops, Via Cavalleggeri 25, 84098 Pontecagnano (Salerno), Italy; massimo.zaccardelli@crea.gov.it

6 Department of Endocrinology of Braga Hospital, Sete Fontes, 4710-243 São Victor, Braga, Portugal; sbsouto.md@gmail.com

7 Department of Biology and Environment, University of Trás-os-Montes e Alto Douro (UTAD), Quinta de Prados, P-5001-801 Vila Real, Portugal; amsilva@utad.pt

8 Centre for Research and Technology of Agro-Environmental and Biological Sciences (CITAB), University of Trás-os-Montes e Alto Douro (UTAD), Quinta de Prados, 5001-801 Vila Real, Portugal

9 Industrial Biotechnology Program, University of Tiradentes (UNIT), Av. Murilo Dantas 300, 49032-490 Aracaju, Brazil; pattypharma@gmail.com

10 Tiradentes Institute, 150 Mt Vernon St., Dorchester, MA 02125, USA

11 Laboratory of Nanotechnology and Nanomedicine (LNMED), Institute of Technology and Research (ITP), Av. Murilo Dantas, 300, 49010-390 Aracaju, Brazil

12 Department of Pharmacy, University of Napoli Federico II, Via D. Montesano 49, 80131 Napoli, Italy; ettore.novellino@unina.it

* Correspondence: ebsouto@ff.uc.pt (E.B.S.); asantini@unina.it (A.S.); Tel.: +351-239-488-400 (E.B.S.); $+39-81-253-9317$ (A.S.)

Received: 14 May 2020; Accepted: 10 July 2020; Published: 16 July 2020

Abstract: Medicinal plants are used worldwide due to their lower risk of side effects and eco-friendly, cost-effective production when compared to chemical drugs, encouraging researchers to further exploit the therapeutic potential of the former. One of the most popular medicinal plants is Vitex agnus-castus L., grown in tropical and sub-tropical regions, to which different health benefits have already been attributed. In this perspective article, the in vitro and in vivo therapeutic properties of V. agnus-castus L. have been analyzed and reviewed with a special focus on its health-promoting effects and potential nutraceutical applications.

Keywords: chaste tree; Vitex agnus-castus L.; bioactive compounds; in vitro studies; in vivo studies; nutraceuticals; health-promoting properties.

\section{Introduction}

Medicinal wild plants and herbs have been considered worldwide for centuries as valuable tools in the management of different diseases, due to their ease of use and improved cost-effectiveness when compared to chemical remedies obtained from synthesis [1]. Plants have recently been exploited 
for nutraceutical purposes, as they play a key role in the development of food and plant-derived phytocomplexes with medicinal properties, to be used in health conditions as preventive or curative tools [2-23]. A popular medicinal plant with recognized beneficial effects on human health is Vitex agnus-castus L., belonging to the Lamiaceae family (formerly included in the Verbenaceae family), native to the Mediterranean area and diffused in Europe, Asia, and North Africa [24,25]. It has been used by people in Italy, Iran, Greece, and Egypt for over 2500 years, mainly to treat gynecologic disorders [26]. It is a globally famous plant known by different names, e.g. Fruit de gattilier (French), Sauzgatillo (Spanish), Mönchspfefferfrüchte (German), Panj-angosht (Persian), Frutto di Agnocasto (Italian), and Chaste tree (English) [27].

The term agnus-castus combines the Greek ( $\dot{\alpha} \gamma v o \tilde{v} \varsigma$, meaning pure, chaste) and the Latin (castus from "castitas" meaning chastity), repeating the term chaste for "pure", which refers to the anaphrodisiac properties of this plant and its use by monks to maintain celibacy (thus the "monk's pepper" synonym). The word "castus" has been used for centuries to remark further the meaning or purity associated with this plant. Homer, the semi-legendary author of the Iliad and the Odyssey epic poems, defines agnus-castus as a "tendril for braiding", explaining the origin of the genus "Vitex". Dioscorides, the Greek physician, used to suggest V. agnus-castus to decrease libido. Pliny the Elder, the famous Roman author, naturalist, and natural philosopher, commented that this herb was scattered on the beds of Athenian women when husbands went to war to ensure their loyalty. Pietro Andrea Mattioli, an Italian physician and botanist of the XVI century, commented in his text "Compendium de Plantis Omnibus una cum Earum Iconibus" (1571) with reference to the properties of V.agnus-castus L. that: "... it forces the impulses of Venus when eaten either fried or raw ... .....it is believed that not only eating or drinking it will make chaste men but even lying on it ...". V. agnus-castus is also known as "monk's pepper" since the fruits of this plant have a bitter taste, and the plant used to be cultivated by monks in their gardens as an anaphrodisiac, according to a legend, to help them not betray their vow of chastity.

Vitex agnus-castus L. fruits have been traditionally consumed as food to enhance milk volume and to treat flatulence and diarrhea as well as cyclic breast pain, menopause, acne, infertility, premenstrual dysphoric disorder and other menstrual disorders (amenorrhea, dysmenorrhea) [28].

The European Medicines Agency and the German Health Commission have reported many health benefits of this medicinal plant, including regulation of the menstrual cycle and treatment of premenstrual syndrome, and mastalgia [29]. This paper is focused on a perspective analysis of the health-promoting effects of $V$. agnus-castus L. and its nutraceutical potential. There are many reported data on the different beneficial health-promoting potentials of this plant, including antioxidant, immunomodulatory, cytotoxic, antimutagenic, antimicrobial, antifungal, antinociceptive, opioidergic, antiepileptic, and anti-inflammatory properties, as well as benefits for osteopenic syndromes, as shown in Figure 1 [30-34]. 


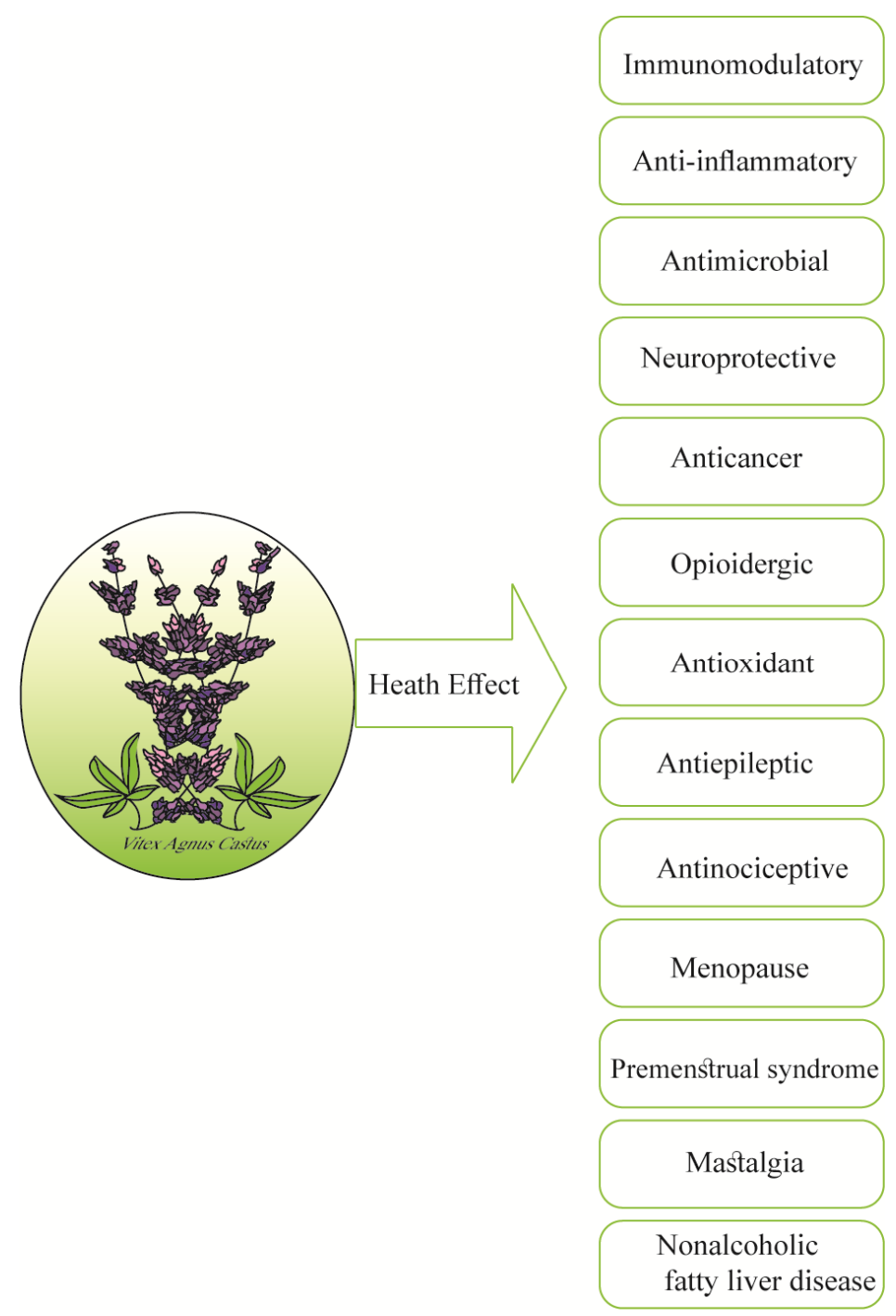

Figure 1. Scheme of the beneficial properties of Vitex agnus-castus L.

\section{Main Substances of Nutraceutical Interest in Vitex agnus-castus}

The chemical composition of Vitex agnus-castus L. includes many different chemical compounds, among which are: vitexilactone, rolundifuran, ketosteroids, diterpenoids (vitexlactam, vitexilactone, viteagnusin I, and rotundifuran), flavonoids (orientin, kaempferol, penduletin, luteolin, artemetin, vitexin, and casticin), and iridoids (agnuside, agnusoside, agnucastosid A/B, and aucubin) [35-37]. The identification and quantification of agnuside (Figure 2), together with $p$-hydroxy benzoic acid, can be achieved by high-performance liquid chromatography HPLC) [38]. This method has been validated for extracts of the species Vitex negundo L. and Vitex trifolia L., with limits of quantification and detection of $25 \mu \mathrm{g} / \mathrm{mL}$ and $10 \mu \mathrm{g} / \mathrm{mL}$, respectively [38]. 
<smiles>O=c1cc(-c2ccc(O)cc2)oc2c([C@@H]3O[C@H](CO)[C@@H](O)[C@H](O)[C@H]3O)c(O)cc(O)c12</smiles>

Vitexin<smiles>O=C(OCC1=C[C@H](O)[C@@H]2C=CO[C@@H](O[C@H]3CO[C@H](CO)[C@@H](O)[C@@H]3O)[C@@H]12)c1ccc(O)cc1</smiles>

Agnuside

(a)

(b)

Figure 2. Chemical structure of vitexin (a) and of agnuside (b).

Gokbulut et al. measured the levels of vitexin (Figure 2), isolated from V. agnus-castus L. fruit and leaf extracts, using the RP-HPLC-DAD (diode array detector) technique, and the results showed that this flavonoid was present in considerable amounts $(0.342 \pm 0.0153 \%$ and $0.252 \pm 0.0089 \%$, respectively) [39].

Agnuside together with casticin (a tetramethoxyflavone) have been used as fingerprint markers to evaluate the quality of Japanese commercial products containing V.agnus-castus L. [40]. Another marker validated for quality assessment was reported by Yahagi et al., using a liquid chromatography-mass spectrometry (LC-MS)-based metabolomic technique and nuclear magnetic resonance (NMR) spectroscopy to detect 3-O-trans-feruloyl tormentic acid, which was isolated from the V. agnus-castus L. fruit extract [41]. In another study, using a rapid ultra-high performance liquid chromatography diode array detector (UHPLC-DAD-QTOF-MS), seven markers of V. agnus-castus L. fruit extract were claimed to be used as reference compounds for quality validation of medicinal products containing this extract, in particular, vitetrifolin D (labdane diterpenoid), 5-hydroxykaempferol-3,6,7,4'-tetramethylether, casticin, isovitexin, and agnuside compounds [42]. A study conducted to compare the chemical markers occurring in food supplements and in V. agnus-castus L. extracts, using the liquid chromatography electrospray triple quadrupole tandem mass spectrometry (LC/ESI/(QqQ)MSMS) method in multiple reaction monitoring (MRM) mode as a quantitative analysis, reported the presence of aucubin, orientin, luteolin-7-O-glucoside, agnuside, isovitexin, homoorientin, and casticin compounds [43]. According to the findings from RP-HPLC-DAD analysis, $V$. agnus-castus L. leaf and fruit extracts contained chlorogenic and caffeic acid phenolic compounds with average concentrations of $0.27 \%$ and $0.32 \%(w / w)$, respectively [44]. Li et al. isolated eighteen compounds from $V$. agnus-castus L. fruit extract, using 1D/2D NMR and mass spectrometry methods, and their chemopreventive potential was studied in Hepa 1c1c7 cells, which showed NADP(H): quinone oxidoreductase type 1 (QR1) induction potential related, with vitetrifolin $D$ and vitexlactam $C$ being the most promising [45]. In another study, the method of supercritical carbon dioxide was used to detect the compounds dihydroselarene, $\alpha$-terpinyl acetate, trans-caryophyllene, sabinene, and 1,8-cineole [46]. Ono et al. applied HPLC coupled with NMR analysis to determine the chemical constituents of V. agnus-castus L. fruits, reporting that viteagnuside was the main compound present [47].

\section{An Updated Snapshot of In Vitro and In Vivo Studies on Vitex agnus-castus}

In-depth knowledge of the phytochemical composition of any potential medicinal plant is the first step for the determination of its beneficial health properties. In the following, the main findings 
regarding beneficial health effects from in vitro and in vivo studies are reported. This information gives an updated picture of the many activities of the compounds contained in this plant, outlining its possible prospective application in the prevention and even in the treatment of pathological conditions.

\subsection{Health-Promoting Activities of Vitex agnus-castus L. In Vitro}

The in vitro health-promoting potential of $V$. agnus-castus L. has been reported in the past [48]. Table 1 summarizes the main results of in vitro studies. V. agnus-castus fruit extract showed in vitro anticancer activity against HL-60 cells by arresting the cell cycle at the G2/M phase and by inducing apoptosis [49]. Abdel-Lateef et al. [50] analyzed the chemical composition of V. agnus-castus L. leaf extract and found it to be composed of phenolic acids, flavonoids, and iridoids, which could significantly prevent HepG2 cell proliferation by inducing apoptosis through caspase-3 activation, with the butanolic fraction being the most active $\left(\mathrm{IC}_{50}=13.42 \pm 0.17 \mathrm{mg} / \mathrm{mL}\right)$. The cytotoxic effect of agnuside was assayed in a colon cancer cell line (COLO $320 \mathrm{DM})$, showing an $\mathrm{IC}_{50}$ value of $15.99 \mu \mathrm{g} / \mathrm{mL}$, and $76.1 \%$ cytotoxic activity at $200 \mu \mathrm{g} / \mathrm{mL}$ [51]. Cytotoxic activity of V. agnus-castus L. fruit extract against other another human colon carcinoma cell line (COLO 201) was shown, by inducing activation of caspase 3/9 leading to apoptosis [52]. Ribat et al. [53] described antiproliferative and anticancer properties of V. agnus-castus L. fruit methanol extract, showing that normal rat embryonic fibroblast cells were much less sensitive than AMN3 cells (mouse mammary gland adenocarcinoma cell line), with $\mathrm{IC}_{50}$ values of $1324 \mu \mathrm{g} / \mathrm{mL}$ and $129 \mu \mathrm{g} / \mathrm{mL}$, respectively. A synergistic effect was observed with co-administration of 5-fluorouracil and $10 \mu \mathrm{g} / \mathrm{mL}$ vitex (ethanolic extract of $V$. agnus-castus L. fruits), using colon cancer cell lines [54]. Casticin extracted from V. agnus castus L. showed cytotoxic and immunomodulatory properties by inhibiting phytohemagglutinin (PHA) induced T-cell proliferation, phagocytosis, and chemotaxis [55]. Sarac et al. reported $56.18 \%$ and $72.25 \%$ antimutagenic activities for the ethanolic extracts of $V$. agnus castus L. seed and leaf at the doses of $2.5 \mathrm{mg} / \mathrm{plate}$ and $0.125 \mathrm{mg} / \mathrm{plate}$, respectively [56].

Table 1. In vitro reported activities for V. agnus-castus L.

\begin{tabular}{|c|c|c|c|c|c|}
\hline Condition & Plant Part & Extract & Activity & Effect & Reference \\
\hline In vitro & Fruits & Ethyl acetate & $\begin{array}{l}\text { Antioxidant } \\
\text { activity }\end{array}$ & $\begin{array}{l}\text { Lipid peroxidation was inhibited by } \\
\text { casticin with an } \mathrm{IC}_{50} \text { value of } 0.049 \mathrm{mM} \text {. }\end{array}$ & [57] \\
\hline In vitro & Leaves & $\begin{array}{l}\text { Supercritical } \\
\mathrm{CO}_{2}\end{array}$ & $\begin{array}{l}\text { Antifungal } \\
\text { activity }\end{array}$ & $\begin{array}{l}\text { The antifungal potential of essential oil } \\
\text { with an MIC value of } 0.64 \mu \mathrm{L} / \mathrm{mL} \text {. }\end{array}$ & [58] \\
\hline In vitro & Leaves & Hydrodistillation & $\begin{array}{l}\text { Antifungal } \\
\text { activity }\end{array}$ & $\begin{array}{l}\text { The antimutagenic activity of } V . \\
\text { agnus-castus leaf extract against } \\
\text { Salmonella typhimurium. }\end{array}$ & [56] \\
\hline In vitro & Aerial parts & $\begin{array}{l}\text { Methanolic } \\
\text { extract (Cr. } \\
\text { MeOH Ext.) }\end{array}$ & $\begin{array}{l}\text { Antimicrobial } \\
\text { activity }\end{array}$ & $\begin{array}{c}\text { The V. agnus-castus leaf essential oil } \\
\text { showed an antibacterial effect against } \\
\text { Staphylococcus aureus with an MIC value } \\
\text { of } 0.31 \% v / v \text {. }\end{array}$ & [59] \\
\hline In vitro & Seed & n-hexane & $\begin{array}{l}\text { Antifungal } \\
\text { activity }\end{array}$ & $\begin{array}{l}\text { Essential oil was effective against } \\
\text { Candida species with an MIC50 value of } \\
1.75 \mathrm{mg} / \mathrm{mL} \text {. }\end{array}$ & {$[60]$} \\
\hline In vitro & $\begin{array}{l}\text { Ripened fruits and } \\
\text { fruitless aerial } \\
\text { parts }\end{array}$ & Ethanol & $\begin{array}{l}\text { Anticancer } \\
\text { activity }\end{array}$ & $\begin{array}{l}\text { Cytotoxic effect of } V \text {. agnus-castus fruit } \\
\text { extract against MCF-7 cancer cells with } \\
\qquad \mathrm{IC}_{50}=88 \mu \mathrm{g} / \mathrm{mL} \text {. }\end{array}$ & {$[61]$} \\
\hline In vitro & Fruits & $\begin{array}{l}\text { Chloroform- } \\
\text { methanol } \\
(250: 1)\end{array}$ & $\begin{array}{l}\text { Anticancer } \\
\text { activity }\end{array}$ & $\begin{array}{c}\text { The cytotoxicity was due to } \\
\text { differentiation of the hematopoietic cell } \\
\text { line. }\end{array}$ & [62] \\
\hline In vitro & Fruits & Ethanol & $\begin{array}{l}\text { Anticancer } \\
\text { activity }\end{array}$ & $\begin{array}{l}\text { Enhanced apoptosis and decreased } \\
\text { intracellular ROS levels. }\end{array}$ & [49] \\
\hline In vitro & Leaves & Methanol & $\begin{array}{l}\text { Antioxidant } \\
\text { effect }\end{array}$ & $\begin{array}{l}\text { The free radical scavenging effect of } V \text {. } \\
\text { agnus-castus methanol extract with an } \\
\mathrm{IC}_{50} \text { value of } 126.79 \mathrm{mg} / \mathrm{mL} \text {. }\end{array}$ & [63] \\
\hline
\end{tabular}


The health of humans, animals, and the food chain is directly and indirectly influenced by various pathogens. Thus, extensive studies have been conducted to control such microorganisms using different approaches, among which the use of cost-effective and more effective natural plant extracts or essential oil has attracted further attention; for example, V. agnus-castus L. has been studied against several pathogenic species such as Staphylococcus aureus, Escheria coli, Bacillus subtilis, and Pseudomonas aeruginosa. Habbab et al. [64] evaluated the antifungal activity of V. agnus-castus flower and leaf essential oils against Aspergillus flavus and Penicillium escpansum, as well as the antibacterial activity of $V$. agnus-castus L. seed and leaf essential oils against $P$. aeruginosa, E. coli, and Klebsiella pneumonia. Vitex agnus-castus L. essential oil was shown to exhibit antibacterial activity against Staphylococcus aureus [65]. Afarin et al. [66] observed in vitro antimicrobial activity for V. agnus-castus L. essential oil at doses of 112.5 and $56.25 \mu \mathrm{g} / \mathrm{mL}$ against Candida albicans and S. aureus, respectively. Katiraee et al. [67] found radical scavenging $\left(\mathrm{IC}_{50}=27.16 \mu \mathrm{g} / \mathrm{mL}\right)$ and antifungal properties for $V$. agnus-castus L. essential oil. Others reported that $V$. agnus-castus L. essential oil showed antifungal potential against Sclerotinia sclerotiorum and Verticillium dahlia with $\mathrm{LC}_{50}$ values of $3.322 \mu \mathrm{g} / \mathrm{mL}$ and $1.063 \mu \mathrm{g} / \mathrm{mL}$, and $9.729 \mu \mathrm{g} / \mathrm{mL}$ and $7.313 \mu \mathrm{g} / \mathrm{mL}$, respectively [68]. Stojković et al. [69] reported antimicrobial potential for $V$. agnus-castus L. fruit and leaf essential oils attributed to the presence of $\alpha$-pinene and 1,8-cineole. The administration of active ethyl acetate extract of $V$. agnus-castus $\mathrm{L}$. leaf exhibited antibacterial potential against methicillin-resistant S. aureus (MIC $=0.312 \mathrm{mg} / \mathrm{mL}$ ) owing to steroids, terpenoids, and flavonoids [70]. Vitex agnus-castus L. leaf essential oil eliminated the cariogenic bacteria Streptococcus mutans (MIC $=15.6 \mu \mathrm{g} / \mathrm{mL}$ ) [71]. In another study, alcoholic and aqueous extracts had an antifungal effect on C. albicans isolated from clinical vaginal infections [72]. Vitex agnus-castus L. seed essential oil showed antifungal activity against Candida species $\left(\mathrm{IC}_{50}=1.072 \mathrm{mg} / \mathrm{mL}\right)$ and also antioxidant potential [73].

The anticancer activity of Vitex agnus-castus L. seed extracts against MCF-7 cells showed DNA-damaging, cytotoxic, and apoptotic effects, and this extract also showed antioxidant properties [74]. Rashed et al. [75] stated that the antioxidant effect of ethyl acetate extract of $V$. agnus castus could be attributed to flavonoids and tannins, as the main compounds. The antioxidant effect of V.agnus-castus L. fruit and leaf extract was confirmed by the decolorization of the radical monocation of 2,2'-azinobis-(3-ethylbenzothiazoline-6-sulfonic acid) (ABTS) assay [76]. Maltaş et al. described a $\mathrm{H}_{2} \mathrm{O}_{2}$ scavenging effect for $V$. agnus-castus L. extract with antioxidant activity of $93.5 \pm 0.8 \%$ [77]. In another study, using ethanolic extract of $V$. agnus-castus L. leaf, containing mainly flavonoids and phenols as active ingredients, it was revealed that there was a direct correlation between these compounds and antioxidant properties [78]. Ahmad et al. [79] reported that vitexcarpan, isolated from the aerial parts of $V$. agnus-castus L. by extraction using ethyl acetate, showed anti-inflammatory activity in activated human neutrophils. The presence of casticin in V. agnus-castus L. extract exhibited anti-inflammatory potential with an efficacy of $69.51 \%$ and an $\mathrm{IC}_{50}$ value of $302.1 \mu \mathrm{g} / \mathrm{mL}$ [80].

Vitex agnus-castus L. fruit extract showed antiangiogenic activity due to the presence of antiangiogenic compounds, confirmed by phytochemical analysis [81].

\subsection{Health-Promoting Activities of Vitex agnus-castus L. in Animals}

There are numerous therapeutic effects of $V$. agnus-castus L. described in animal models. Table 2 reports the results of the main animal model studies. Oral administration of $V$. agnus-castus L. extract $(200 \mathrm{mg} / \mathrm{kg})$ in Sprague-Dawley rats with a mammary tumor for 15 days improved the oxidative status of the mammary tumor tissue and treated tumor regression properties [82]. 
Table 2. Animal model reported activities for V. agnus-castus L.

\begin{tabular}{|c|c|c|c|c|c|}
\hline Condition & Plant Part & Extract & Activity & Effect & Reference \\
\hline Animal model & Leaves & Hydrodistillation & $\begin{array}{l}\text { Antinociceptive } \\
\text { activity and } \\
\text { analgesic effect }\end{array}$ & $\begin{array}{l}\text { The analgesic activity was } \\
\text { due to the activation of } \\
\text { muscarinic receptors of the } \\
\text { cholinergic system and } \\
\text { endogenous opioidergic } \\
\text { system. }\end{array}$ & [83] \\
\hline Animal model & $\begin{array}{l}\text { Stems and } \\
\text { leaves }\end{array}$ & Ethanol & $\begin{array}{l}\text { Treatment of } \\
\text { polycystic ovary } \\
\text { syndrome }\end{array}$ & $\begin{array}{l}\text { V. agnus-castus exhibited } \\
\text { hypoglycemic, antioxidant, } \\
\text { and antihyperlipidemic } \\
\text { activities in rats. }\end{array}$ & [84] \\
\hline Animal model & Fruits & $\begin{array}{l}\text { Chloroform, } \\
\text { methanol, and } \\
\text { water }\end{array}$ & $\begin{array}{l}\text { Antihyperlipidemic } \\
\text { activity }\end{array}$ & $\begin{array}{l}\text { The } V \text {. agnus-castus extract } \\
(500 \mathrm{mg} / \mathrm{kg} \text { for } 28 \text { days) } \\
\text { decreased the levels of } \\
\text { VLDL, LDL, TG, and TC. }\end{array}$ & [85] \\
\hline Animal model & Fruits & $\begin{array}{l}\text { Hexane, ethyl } \\
\text { ether, and } \\
\text { n-butanol }\end{array}$ & $\begin{array}{c}\text { Protected against } \\
\text { nonalcoholic fat } \\
\text { liver disease }\end{array}$ & $\begin{array}{l}\text { Prevented oxidative stress } \\
\text { and treated nonalcoholic fat } \\
\text { liver disease. }\end{array}$ & [86] \\
\hline Animal model & Berries & Ethanol & $\begin{array}{l}\text { Anti-inflammatory } \\
\text { activity }\end{array}$ & $\begin{array}{l}\text { Inhibited the production of } \\
\text { reactive oxygen species, the } \\
\text { release of cytokines, and the } \\
\text { formation of leukotriene. }\end{array}$ & [87] \\
\hline Animal model & Leaves & Chloroform & $\begin{array}{l}\text { Antiangiogenic } \\
\text { activity }\end{array}$ & $\begin{array}{l}\text { Prevented growth of } \\
\text { psoriasis, cataract, and } \\
\text { tumor. }\end{array}$ & [88] \\
\hline Animal model & Fruits & Ethanol & Antiaging effects & $\begin{array}{c}\text { Improved } \\
\text { D-galactose-induced aging } \\
\text { symptoms, including } \\
\text { enhanced serum LH and } \\
\text { FSH levels, follicle } \\
\text { degeneration, and } \\
\text { endometrial atrophy. }\end{array}$ & [89] \\
\hline Animal model & Fruits & Methanol & $\begin{array}{l}\text { Antiepileptic } \\
\text { activity }\end{array}$ & $\begin{array}{c}\text { Reduced stage } 5 \text { duration } \\
\text { and after-discharge } \\
\text { duration. }\end{array}$ & [90] \\
\hline Animal model & Fruits & Ethanol & $\begin{array}{l}\text { Osteoprotective } \\
\text { effects }\end{array}$ & $\begin{array}{l}\text { Enhanced biomechanical } \\
\text { stability of bone via } \\
\text { connectivity density in the } \\
\text { orchidectomized rats and } \\
\text { improved the trabecular } \\
\text { microarchitecture. }\end{array}$ & [91] \\
\hline Animal model & Leaves & Methanol & $\begin{array}{c}\text { Anti-inflammatory } \\
\text { effect }\end{array}$ & $\begin{array}{l}\text { The V. agnus-castus methanol } \\
\text { extract }(400 \mathrm{mg} / \mathrm{kg}) \text { reduced } \\
\text { IL- } 6 \text { and TNF- } \alpha \text { levels. }\end{array}$ & [92] \\
\hline Animal model & - & $\begin{array}{l}\text { Methanol, } \\
\text { n-hexane, and } \\
\text { Ethyl acetate }\end{array}$ & $\begin{array}{l}\text { Antioxidant and } \\
\text { antiapoptotic } \\
\text { effects }\end{array}$ & $\begin{array}{l}\text { Vitexilactone extracted from } \\
\text { V. agnus-castus reduced } \\
\text { caspase-3 and apoptosis } \\
\text { marker expression in } \\
\text { Sprague-Dawley rats. }\end{array}$ & [93] \\
\hline
\end{tabular}

The administration of casticin extracted from $V$. agnus-castus L. fructus $(1,2$, and $10 \mathrm{mg} / \mathrm{Kg}$ per day) for two weeks protected inflammatory lung diseases in a mouse model due to an anti-inflammatory effect by decreasing epithelium thickness, perivascular inflammatory cells, and peribronchial infiltration, as well as reduced the numbers of total cells, lymphocytes, macrophages, and neutrophils [94]. The administration of $V$. agnus-castus L. fruit extract $(165 \mathrm{mg} / \mathrm{Kg} /$ day) in rats controlled prostate cancer by inducing apoptosis and showed an anti-inflammatory effect by inhibiting cyclooxygenase-2 activity [95]. Webster et al. reported that V. agnus-castus attenuates pre-menstrual syndrome [96]. 
Vitex agnus-castus administered for five days protected mice against lipopolysaccharide (LPS)-induced acute lung damage, due to an antioxidant effect [97]. The methanol extract of $V$. agnus-castus leaf showed an antiangiogenic effect in an ex vivo rat aorta, and also antioxidant activity with an $\mathrm{IC}_{50}$ value of $126.79 \mu \mathrm{g} / \mathrm{mL}$ [88].

Moreover, administration of $V$. agnus castus ethanolic extract ( 8 and $80 \mathrm{mg} / \mathrm{Kg} / \mathrm{day}$ ) for three months in ovariectomized rats improved memory and learning via decreasing uterine weight and increasing the estrogen receptor $E R \alpha$ gene expression, respectively, suggesting a solution for memory loss in postmenopausal women [98]. The hydroalcoholic extract of $V$. agnus-castus fruits $(600 \mathrm{mg} / \mathrm{Kg}$ twice a day) reduced age-related changes in a female mice model after 7 days [99].

$V$. agnus-castus extract was administered to a mouse model of permanent middle cerebral artery occlusion for 30 days, and it was observed that the anti-inflammatory and estrogenic activities reduced stroke injuries. Moreover, this study also reported neuroprotective activity by reducing matrix metalloproteinase-9 (MMP-9), increasing interleukin 10, and improving adhesive removal and wire hanging test performance [100].

\subsection{Health-Promoting Activities of Vitex agnus-castus L. in Humans, with Particular Regard to Clinical Trials}

Many clinical trials confirm the health-promoting effects of V. agnus-castus L. [101-108]. Table 3 reports the results of the main clinical trial studies. Naseri et al. [109] reported a reduction in menopausal symptoms after taking V. agnus-castus L. extracts. The authors allocated the participants into two placebo groups and a Vitex-treated group, and then assessed menopausal symptoms before and after an 8-week intervention using the Greene Questionnaire [110]. After the intervention, the Vitex group showed a reduction in vasomotor dysfunction, anxiety, and total menopausal disorder. Yavarikia et al. [111] administered $V$. agnus-castus L. capsules to female participants three times a day for four months, and obtained data with the Higham five-stage chart (for 1 month before the treatment and 4 months during the treatment) [112] and a demographic questionnaire. They found a $47.6 \%$ decrease in bleeding in the V. agnus-castus L. group. Oral administration of ethanolic extract of V. agnus-castus L. (4.0 mg), dried as film-coated tablets, in Chinese women with premenstrual syndrome (PMS) reduced the PMS score of the third cycle from 27.10 to 14.59 in the case group [113]. Daily administration of V. agnus-castus L. extract-containing tablets in Chinese women with premenstrual syndrome (PMS) decreased the PMS scores of symptoms such as pain, food cravings, and water retention [114]. A self-assessment questionnaire was completed for the symptoms of PMS in women after taking 40 drops of $V$. agnus-castus L. extract for 6 days, the results of which showed mild to moderate relief in PMS symptoms [115]. In a recent clinical trial, it was reported that the administration of V. agnus-castus L. in women with polycystic ovary syndrome reduced the level of dehy-droepiandrosterone sulfate (DHEA-S) and normalized the menstrual cycle [116]. Healthy menopausal women co-administrated V. agnus-castus L. and Nigella sativa with citalopram once a day for 8 weeks showed superior scores in three of the Menopause-specific Quality of Life Questionnaire (MENQOL) domains: psychosocial $(p=0.001)$, physical $(p=0.036)$, and vasomotor $(p<0.001)$ [117]. 
Table 3. Clinical trials reporting V. agnus-castus L. activities.

\begin{tabular}{|c|c|c|c|c|}
\hline Condition & Activity & Administration & Effect & Reference \\
\hline Clinical trial & $\begin{array}{l}\text { Treatment of } \\
\text { vasomotor } \\
\text { symptoms. }\end{array}$ & $\begin{array}{l}\text { The administration of } V \text {. } \\
\text { agnus-castus ( } 40 \mathrm{mg} \text { ) once a } \\
\text { day for a month in women } \\
\text { with postmenopausal } \\
\text { symptoms. }\end{array}$ & $\begin{array}{l}\text { Improvement of } \\
\text { sleep satisfaction. }\end{array}$ & [118] \\
\hline Clinical trial & $\begin{array}{c}\text { Treatment of } \\
\text { mastalgia. }\end{array}$ & $\begin{array}{l}\text { The administration of } V \text {. } \\
\text { agnus-castus in patients with } \\
\text { mastalgia. }\end{array}$ & $\begin{array}{l}\text { Reduction in } \\
\text { prolactin level after } \\
\text { three months. }\end{array}$ & [119] \\
\hline Clinical trial & $\begin{array}{l}\text { Treatment of } \\
\text { premenstrual } \\
\text { syndrome. }\end{array}$ & $\begin{array}{c}\text { Administration of } V \text {. } \\
\text { agnus-castus extract }(20 \mathrm{mg}) \\
\text { once a day for three } \\
\text { menstrual cycles in Japanese } \\
\text { women. }\end{array}$ & $\begin{array}{l}\text { The symptoms of } \\
\text { premenstrual } \\
\text { syndrome were } \\
\text { improved. }\end{array}$ & [120] \\
\hline Clinical trial & $\begin{array}{l}\text { Treatment of } \\
\text { premenstrual } \\
\text { syndrome. }\end{array}$ & $\begin{array}{l}\text { The administration of } V \text {. } \\
\text { agnus-castus ( } 40 \mathrm{mg} \text { ) once a } \\
\text { day for three months in } \\
\text { migrainous women with } \\
\text { premenstrual syndrome. }\end{array}$ & $\begin{array}{l}\text { The symptoms of } \\
\text { premenstrual } \\
\text { syndrome were } \\
\text { reduced in } 66 \\
\text { women. }\end{array}$ & [121] \\
\hline Clinical trial & $\begin{array}{l}\text { Treatment of } \\
\text { premenstrual } \\
\text { syndrome. }\end{array}$ & $\begin{array}{l}\text { The administration of } V \text {. } \\
\text { agnus-castus extract Ze } 440 \\
\text { (20 mg) once a day. }\end{array}$ & $\begin{array}{l}\text { The symptoms of } \\
\text { premenstrual } \\
\text { syndrome were } \\
\text { relieved in women. }\end{array}$ & [122] \\
\hline Clinical trial & $\begin{array}{l}\text { Treatment of } \\
\text { menopausal } \\
\text { syndrome. }\end{array}$ & $\begin{array}{l}\text { The administration of } V \text {. } \\
\text { agnus-castus extract ( } 40 \\
\text { drops) once a day for } 8 \\
\text { weeks in women. }\end{array}$ & $\begin{array}{l}\text { Hot flashes were } \\
\text { positively } \\
\text { influenced by Vitex } \\
\text { in women. }\end{array}$ & [123] \\
\hline Clinical trial & $\begin{array}{l}\text { Treatment of } \\
\text { premenstrual } \\
\text { syndrome. }\end{array}$ & $\begin{array}{l}\text { The co-administration of } V \text {. } \\
\text { agnus-castus with Hypericum } \\
\text { perforatum twice a day for } 16 \\
\text { weeks in women with } \\
\text { premenstrual syndrome. }\end{array}$ & $\begin{array}{l}\text { Symptoms such as } \\
\text { hydration clusters } \\
\text { and anxiety were } \\
\text { alleviated. }\end{array}$ & [124] \\
\hline Clinical trial & $\begin{array}{l}\text { Treatment of } \\
\text { premenstrual } \\
\text { syndrome. }\end{array}$ & $\begin{array}{l}\text { The administration of } V \text {. } \\
\text { agnus-castus extract ( } 40 \\
\text { drops) for } 4 \text { months. }\end{array}$ & $\begin{array}{l}\text { The pregnancy rate, } \\
\text { endometrial } \\
\text { thickness, } \\
\text { ovulation, and } \\
\text { fertility were } \\
\text { increased in } \\
\text { women. }\end{array}$ & [125] \\
\hline Clinical trial & $\begin{array}{l}\text { Prolactin-inhibiting } \\
\text { activity. }\end{array}$ & $\begin{array}{c}\text { The daily administration of } \\
\text { Agnus-castus extract } \\
\text { (BP1O95E1) at a } \\
\text { concentration of } 480 \mathrm{mg} \text { for } \\
\text { two weeks in healthy male } \\
\text { subjects. }\end{array}$ & $\begin{array}{l}\text { Decreased } \\
\text { prolactin profile } \\
\text { levels. }\end{array}$ & [126] \\
\hline
\end{tabular}

Vitex agnus-castus L. extracts have reportedly exhibited many health-promoting effects, but some limitations have been shown for human health such as agitation, headache, nausea, tachycardia, fatigue, dry mouth, urticaria, and gastrointestinal problems [78]. In a study by Owolabi et al. [127], it was also reported that increasing the dose and long-term administration of the Vitex genus induced toxicity in rats. 


\section{Conclusions}

Considering the naturally occurring bioactive compounds with therapeutic potential that it contains, V. agnus-castus L. is one of the best-selling and most widely used medicinal herbs worldwide. Nevertheless, there is a need for further in vivo and in vitro research and more clinical trials to assess the beneficial health compounds content of this plant and the related mechanisms of action in the treatment of various diseases, as it is so far been largely limited to animal model trials and in vitro studies. The clinical trial studies in humans focus on a limited number of health conditions, suggesting the need to exploit what is observed in animal trials and possible in prospective assess also possible applications in humans. The beneficial properties of V. agnus-castus L. trigger interest in the possibility of developing novel nutraceutical formulations, which can help to support health conditions before the need of a pharmacological therapy, in particular for individuals who do not qualify for a conventional drug-based treatment. It should be noted also that there is a need for more comprehensive clinical trials over a long timeframe in order to draw definitive conclusions about the findings related to the various effects and consequences of a long-term consumption of $V$. agnus-castus $\mathrm{L}$.

Author Contributions: E.B.S., A.D., A.N., M.L., E.N., and A.S. conceived and designed the work. E.B.S., A.D., A.N., M.L., M.Z., A.M.S., P.S., E.N., and A.S. wrote the work. A.D., A.N., M.L., M.Z., S.B.S., A.M.S., and P.S. validated and elaborated data information and figures. All authors have read and agreed to the published version of the manuscript.

Funding: The authors acknowledge the support of the research project: Nutraceutica come supporto nutrizionale nel paziente oncologico, CUP: B83D18000140007. E.B.S. acknowledges the sponsorship of the projects M-ERA-NET-0004/2015-PAIRED and UIDB/04469/2020 (strategic fund); A.M.S. acknowledges UIDB/04033/2020 (CITAB), receiving support from the Portuguese Science and Technology Foundation, Ministry of Science and Education (FCT/MEC) through national funds, and co-financed by FEDER under the Partnership Agreement PT2020.

Conflicts of Interest: The authors declare no conflict of interest.

\section{References}

1. Yeung, A.W.K.; Heinrich, M.; Kijjoa, A.; Tzvetkov, N.T.; Atanasov, A.G. The ethnopharmacological literature: An analysis of the scientific landscape. J. Ethnopharmacol. 2020, 250, 112414. [CrossRef] [PubMed]

2. Santini, A.; Novellino, E. Nutraceuticals: Beyond the diet before the drugs. Curr. Bioact. Compd. 2014, 10, 1-12. [CrossRef]

3. Durazzo, A. Extractable and Non-extractable Polyphenols: An Overview. In Non-Extractable Polyphenols and Carotenoids: Importance in Human Nutrition and Health; Saura-Calixto, F., Pérez-Jiménez, J., Eds.; Royal Society of Chemistry: London, UK, 2018.

4. Durazzo, A.; Lucarini, M. A current shot and re-thinking of antioxidant research strategy. Braz. J. Anal. Chem. 2018, 5, 9-11. [CrossRef]

5. Durazzo, A.; Lucarini, M. Extractable and non-extractable antioxidants. Molecules 2019, 24, 1993. [CrossRef] [PubMed]

6. Durazzo, A.; Lucarini, M.; Kiefer, J.; Mahesar, S.A. State-of-the-Art Infrared Applications in Drugs, Dietary Supplements, and Nutraceuticals. J. Spectrosc. 2020, 2020, 1397275. [CrossRef]

7. Durazzo, A.; Lucarini, M. The State of Science and Innovation of Bioactive Research and Applications, Health and Diseases. Front. Nutr. 2019, 6, 178. [CrossRef]

8. Santini, A.; Novellino, E.; Armini, V.; Ritieni, A. State of the art of Ready-to-Use Therapeutic Food: A tool for nutraceuticals addition to foodstuff. Food Chem. 2013, 140, 843-849. [CrossRef]

9. Durazzo, A.; Lucarini, M.; Novellino, E.; Souto, E.B.; Daliu, P.; Santini, A. Abelmoschus esculentus (L.): Bioactive Components' Beneficial Properties-Focused on Antidiabetic Role-For Sustainable Health Applications. Molecules 2019, 24, 38. [CrossRef]

10. Lucarini, M.; Durazzo, A.; Kiefer, J.; Santini, A.; Lombardi-Boccia, G.; Souto, E.B.; Romani, A.; Lampe, A.; Ferrari Nicoli, S.; Gabrielli, P. Grape Seeds: Chromatographic Profile of Fatty Acids and Phenolic Compounds and Qualitative Analysis by FTIR-ATR Spectroscopy. Foods 2020, 9, 10. [CrossRef] 
11. Salehi, B.; Venditti, A.; Sharifi-Rad, M.; Kręiel, D.; Sharifi-Rad, J.; Durazzo, A.; Lucarini, M.; Santini, A.; Souto, E.B.; Novellino, E. The therapeutic potential of apigenin. Int. J. Mol. Sci. 2019, 20, 1305. [CrossRef]

12. Durazzo, A.; Lucarini, M.; Souto, E.B.; Cicala, C.; Caiazzo, E.; Izzo, A.A.; Novellino, E.; Santini, A. Polyphenols: A concise overview on the chemistry, occurrence, and human health. Phytother. Res. 2019, 33, 2221-2243. [CrossRef]

13. Abenavoli, L.; Izzo, A.A.; Milić, N.; Cicala, C.; Santini, A.; Capasso, R. Milk thistle (Silybum marianum): A concise overview on its chemistry, pharmacological, and nutraceutical uses in liver diseases. Phytother. Res. 2018, 32, 2202-2213. [CrossRef] [PubMed]

14. Santini, A.; Tenore, G.C.; Novellino, E. Nutraceuticals: A paradigm of proactive medicine. Eur. J. Pharm. Sci. 2017, 96, 53-61. [CrossRef] [PubMed]

15. Daliu, P.; Santini, A.; Novellino, E. A decade of nutraceutical patents: Where are we now in 2018? Expert Opin. Ther. Pat. 2018, 28, 875-882. [CrossRef] [PubMed]

16. Santini, A.; Novellino, E. Nutraceuticals-shedding light on the grey area between pharmaceuticals and food. Expert Rev. Clin. Pharmacol. 2018, 11, 545-547. [CrossRef]

17. Bircher, J.; Hahn, E.G. Understanding the nature of health: New perspectives for medicine and public health. Improved wellbeing at lower costs: New Perspectives for Medicine and Public Health: Improved Wellbeing at lower Cost. F1000Research 2016, 5, 167. [CrossRef]

18. Santini, A.; Cammarata, S.M.; Capone, G.; Ianaro, A.; Tenore, G.C.; Pani, L.; Novellino, E. Nutraceuticals: Opening the debate for a regulatory framework. Br. J. Clin. Pharmacol. 2018, 84, 659-672. [CrossRef]

19. Daliu, P.; Santini, A.; Novellino, E. From pharmaceuticals to nutraceuticals: Bridging disease prevention and management. Expert Rev. Clin. Pharmacol. 2019, 12, 1-7. [CrossRef]

20. Durazzo, A.; D’Addezio, L.; Camilli, E.; Piccinelli, R.; Turrini, A.; Marletta, L.; Marconi, S.; Lucarini, M.; Lisciani, S.; Gabrielli, P. From plant compounds to botanicals and back: A current snapshot. Molecules 2018, 23, 1844. [CrossRef]

21. Durazzo, A.; Camilli, E.; D’Addezio, L.; Piccinelli, R.; Mantur-Vierendeel, A.; Marletta, L.; Finglas, P.; Turrini, A.; Sette, S. Development of Dietary Supplement Label Database in Italy: Focus of FoodEx2 Coding. Nutrients 2020, 12, 89. [CrossRef]

22. Khasim, S.; Long, C.; Thammasiri, K.; Lutken, H. Medicinal Plants: Biodiversity, Sustainable Utilization and Conservation; Springer: Berlin/Heidelberg, Germany, 2020. [CrossRef]

23. Orbe, I.; Paz, D.; Pejenaute, L.; Puente, A.; de Alda, L.D.; Yague, S.; Lete, I. Medicinal Herbs: Its Therapeutic Use in Obstetrics and Gynaecology. In Approaching Complex Diseases: Network-Based Pharmacology and Systems Approach in Bio-Medicine; Bizzarri, M., Ed.; Springer International Publishing: Berlin/Heidelberg, Germany, 2020; pp. 437-455. [CrossRef]

24. Rani, A.; Sharma, A. The genus Vitex: A review. Pharmacogn. Rev. 2013, 7, 188. [CrossRef] [PubMed]

25. Köngül, E. Agnus Castus. In Nonvitamin and Nonmineral Nutritional Supplements, 1st ed.; Nabavi, S., Silva, A.S., Eds.; Elsevier: Amsterdam, The Netherlands, 2019; pp. 139-143.

26. Roemheld-Hamm, B. Chasteberry. Am. Fam. Physician 2005, 72, 821-824. [PubMed]

27. King, S.R. Medicinal Plants of the World Volume 2: Chemical Constituents, Traditional and Modern Medicinal Uses by Ivan, A. Ross (U.S. Food and Drug Administration). Humana Press, Inc., Totowa, NJ. J. Nat. Prod. 2002, 65, 1085. [CrossRef]

28. Niroumand, M.C.; Heydarpour, F.; Farzaei, M.H. Pharmacological and Therapeutic Effects of Vitex agnus-castus L.: A Review. Pharmacogn. Rev. 2018, 12, 103-114.

29. Girman, A.; Lee, R.; Kligler, B. An integrative medicine approach to premenstrual syndrome. Am. J. Obstet. Gynecol. 2003, 188, S56-S65. [CrossRef]

30. Chan, E.W.C.; Wong, S.K.; Chan, H.T. Casticin from Vitex species: A short review on its anticancer and anti-inflammatory properties. J. Integr. Med. 2018, 16, 147-152. [CrossRef]

31. Mari, A.; Montoro, P.; D’Urso, G.; Macchia, M.; Pizza, C.; Piacente, S. Metabolic profiling of Vitex agnus castus leaves, fruits and sprouts: Analysis by LC/ESI/(QqQ) MS and (HR) LC/ESI/(Orbitrap)/MSn. J. Pharm. Biomed. Anal. 2015, 102, 215-221. [CrossRef]

32. Nigam, M.; Saklani, S.; Plygun, S.; Mishra, A.P. Antineoplastic potential of the Vitex species: An overview. Bol. Latinoam. Caribe Plantas Med. Aromát. 2018, 17, 492-502. 
33. Al Saka, F.; Daghestani, M.; Karabet, F. Composition and Antioxidant Activity of Vitex agnus-castus L. and Rosmarinus Officinalis, L. Leaves Essential Oils Cultivated in Syria. SM Anal Bioanal Tech. 2017, 2, 1010. [CrossRef]

34. Heskes, A.M.; Sundram, T.C.; Boughton, B.A.; Jensen, N.B.; Hansen, N.L.; Crocoll, C.; Cozzi, F.; Rasmussen, S.; Hamberger, B.; Hamberger, B. Biosynthesis of bioactive diterpenoids in the medicinal plant Vitex agnus-castus. Plant J. 2018, 93, 943-958. [CrossRef]

35. Kirmizibekmez, H.; Demir, D. Iridoid Glycosides and Phenolic Compounds from the Flowers of Vitex agnus-castus. Helv. Chim. Acta 2016, 99, 518-522. [CrossRef]

36. Rajić, M.; Molnar, M.; Bilić, M.; Jokić, S. The impact of extraction methods on isolation of pharmacologically active compounds from Vitex agnus-castus-a review. Int. J. Pharm. Res. Allied Sci. 2016, 5, 15-21.

37. Zahid, H.; Rizwani, G.H.; Ishaqe, S. Phytopharmacological review on Vitex agnus-castus: A potential medicinal plant. Chin. Herb. Med. 2016, 8, 24-29. [CrossRef]

38. Shah, S.; Dhanani, T.; Kumar, S. Validated HPLC method for identification and quantification of p-hydroxy benzoic acid and agnuside in Vitex negundo and Vitex trifolia. J. Pharm. Anal. 2013, 3, 500-508. [CrossRef] [PubMed]

39. Gökbulut, A.; Özhan, O.; Karacaoğlu, M.; Şarer, E. Radical scavenging activity and vitexin content of Vitex agnus-castus leaves and fruits. FABAD J. Pharm. Sci. 2010, 35, 85-91.

40. Sogame, M.; Naraki, Y.; Sasaki, T.; Seki, M.; Yokota, K.; Masada, S.; Hakamatsuka, T. Quality Assessment of Medicinal Product and Dietary Supplements Containing Vitex agnus-castus by HPLC Fingerprint and Quantitative Analyses. Chem. Pharm. Bull. 2019, 67, 527-533. [CrossRef]

41. Yahagi, T.; Masada, S.; Oshima, N.; Suzuki, R.; Matsufuji, H.; Takahashi, Y.; Watanabe, M.; Yahara, S.; Iida, O.; Kawahara, N. Determination and identification of a specific marker compound for discriminating Shrub Chaste Tree Fruit from Agnus Castus Fruit based on LC/MS metabolic analysis. Chem. Pharm. Bull. 2016, 64, 305-310. [CrossRef]

42. Högner, C.; Sturm, S.; Seger, C.; Stuppner, H. Development and validation of a rapid ultra-high performance liquid chromatography diode array detector method for Vitex agnus-castus. J. Chromatogr. B 2013, 927, 181-190. [CrossRef]

43. Mari, A.; Montoro, P.; Pizza, C.; Piacente, S. Liquid chromatography tandem mass spectrometry determination of chemical markers and principal component analysis of Vitex agnus-castus L. fruits (Verbenaceae) and derived food supplements. J. Pharm. Biomed. Anal. 2012, 70, 224-230. [CrossRef]

44. Şarer, E.; Gökbulut, A. Determination of caffeic and chlorogenic acids in the leaves and fruits of Vitex agnus-castus. Turk J. Pharm. Sci. 2008, 5, 167-174.

45. Li, S.; Qiu, S.; Yao, P.; Sun, H.; Fong, H.H.; Zhang, H. Compounds from the fruits of the popular European medicinal plant Vitex agnus-castus in chemoprevention via NADP (H): Quinone oxidoreductase type 1 induction. Evid.-Based Complement. Altern. Med. 2013, 2013, 432829. [CrossRef]

46. Eryigit, T.; Çig, A.; Okut, N.; Yildirim, B.; Ekici, K. Evaluation of chemical composition and antimicrobial activity of Vitex agnus castus L. fruits' essential oils from west Anatolia, Turkey. J. Essent. 2015, 18, 208-214.

47. Ono, M.; Eguchi, K.; Konoshita, M.; Furusawa, C.; Sakamoto, J.; Yasuda, S.; Ikeda, T.; Okawa, M.; Kinjo, J.; Yoshimitsu, H. A new diterpenoid glucoside and two new diterpenoids from the fruit of Vitex agnus-castus. Chem. Pharm. Bull. 2011, 59, 392-396. [CrossRef] [PubMed]

48. Onaran, A. In Vitro antifungal activities of some plant extracts against plant pathogenic fungi in Turkey. Egypt. J. Biol. Pest Control 2016, 26, 111.

49. Kikuchi, H.; Yuan, B.; Yuhara, E.; Imai, M.; Furutani, R.; Fukushima, S.; Hazama, S.; Hirobe, C.; Ohyama, K.; Takagi, N. Involvement of histone H3 phosphorylation via the activation of p38 MAPK pathway and intracellular redox status in cytotoxicity of HL-60 cells induced by Vitex agnus-castus fruit extract. Int. J. Oncol. 2014, 45, 843-852. [CrossRef] [PubMed]

50. Abdel-Lateef, E.E.-S.; Hammam, O.A.; Mahmoud, F.S.; Atta, S.A.; El-Sayed, M.M.; Hassenein, H.I. Induction of apoptosis in HepG2 by Vitex agnus-castus L. leaves extracts and identification of their active chemical constituents by LC-ESI-MS. Asian Pac. J. Trop. Dis. 2016, 6, 539-548. [CrossRef]

51. Sa, A.; Kb, P.; Pa, V. Free radical scavenging and in vitro cytotoxicity activity of agnuside from Vitex agnus castus (Verbenacae). J. Pharm. Res. 2012, 5, 2548-2552. 
52. Imai, M.; Yuan, B.; Kikuchi, H.; Saito, M.; Ohyama, K.; Hirobe, C.; Oshima, T.; Hosoya, T.; Morita, H.; Toyoda, H. Growth inhibition of a human colon carcinoma cell, COLO 201, by a natural product, Vitex agnus-castus fruits extract, in vivo and in vitro. Adv. Biol. Chem. 2012, 2, 20-28. [CrossRef]

53. Ribat, Z.W.; Sahib, H.B.; Al-Shammari, A.M. Effect of vitex agnus castus fruits methanol extract against murine mammary adenocarcinoma cell line (amn3) and rat embryonic fibroblast normal cell line (ref). Int. J. Res. Pharm. Sci. 2019, 10, 1910-1913.

54. Imai, M.; Kikuchi, H.; Yuan, B.; Aihara, Y.; Mizokuchi, A.; Ohya-Ma, K.; Hirobe, C.; Toyoda, H. Enhanced growth inhibitory effect of 5-fluorouracil in combination with Vitex agnus-castus fruits extract against a human colon adenocarcinoma cell line, COLO 201. J. Chin. Clin. Med. 2011, 6, 14-19.

55. Mesaik, M.A.; Murad, S.; Khan, K.M.; Tareen, R.B.; Ahmed, A.; Choudhary, M.I. Isolation and immunomodulatory properties of a flavonoid, casticin from Vitex agnus-castus. Phytother. Res. 2009, 23, 1516-1520. [CrossRef] [PubMed]

56. Sarac, N.; Ugur, A.; Sen, B. In vitro antimutagenic activity of Vitex agnus-castus L. essential oils and ethanolic extracts. Ind. Crop. Prod. 2015, 63, 100-103. [CrossRef]

57. Hajdú, Z.; Hohmann, J.; Forgo, P.; Martinek, T.; Dervarics, M.; Zupkó, I.; Falkay, G.; Cossuta, D.; Máthé, I. Diterpenoids and flavonoids from the fruits of Vitex agnus-castus and antioxidant activity of the fruit extracts and their constituents. Phytother. Res. 2007, 21,391-394. [CrossRef] [PubMed]

58. Marongiu, B.; Piras, A.; Porcedda, S.; Falconieri, D.; Gonçalves, M.J.; Salgueiro, L.; Maxia, A.; Lai, R. Extraction, separation and isolation of volatiles from Vitex agnus-castus L.(Verbenaceae) wild species of Sardinia, Italy, by supercritical CO2. Nat. Prod. Res. 2010, 24, 569-579. [CrossRef]

59. Ahmad, B.; Hafeez, N.; Ara, G.; Azam, S.; Bashir, S.; Khan, I. Antibacterial activity of crude methanolic extract and various fractions of Vitex agnus castus and Myrsine africana against clinical isolates of Methicillin Resistant Staphylococcus aureus. Pak. J. Pharm. Sci. 2016, 29, 1977-1983. [PubMed]

60. Asdadi, A.; Idrissi Hassani, L.; Chebli, B.; Moutaj, R.; Gharby, S.; Harhar, H.; Salghi, R.; El Hadek, M. Chemical composition and antifungal activity of vitex agnus-castus L. seeds oil growing in Morocco. J. Mater. Environ. Sci. 2014, 5, 823-830.

61. Ağalar, H.G.; Çiftçi, G.A.; Gögera, F.; Kırımera, N. The LC/ESI-MSMS Profiles and Biological Potentials of Vitex agnus castus Extracts. Nat. Prod. Commun. 2016, 11, 1655-1660. [CrossRef]

62. Kikuchi, H.; Yuan, B.; Nishimura, Y.; Imai, M.; Furutani, R.; Kamoi, S.; Seno, M.; Fukushima, S.; Hazama, S.; Hirobe, C. Cytotoxicity of Vitex agnus-castus fruit extract and its major component, casticin, correlates with differentiation status in leukemia cell lines. Int. J. Oncol. 2013, 43, 1976-1984. [CrossRef] [PubMed]

63. Sahib, H.B.; Al-Zubaidy, A.A.; Hussein, S.M.; Dahham, S.S.; Al-Suede, F.S.; Shah, A.M. The Anti-proliferative Activity of Vitex agnus-castus Leaves Methanol Extract against Breast and Prostate Cancer Cell Line. Am. J. Phyto Clin. Ther. 2015, 3, 2321-2748.

64. Habbab, A.; Sekkoum, K.; Belboukhari, N.; Cheriti, A.Y.; Aboul-Enein, H. Essential oil chemical composition of Vitex agnus-castus L. from Southern-West Algeria and its antimicrobial activity. Curr. Bioact. Compd. 2016, 12, 51-60. [CrossRef]

65. Ghannadi, A.; Bagherinejad, M.; Abedi, D.; Jalali, M.; Absalan, B.; Sadeghi, N. Antibacterial activity and composition of essential oils from Pelargonium graveolens L'Her and Vitex agnus-castus L. Iran. J. Microbiol. 2012, 4, 171. [PubMed]

66. Afarin, H.; Dakhili, M.; Zolfaghari, M.R. Comparison of antimicrobioal effect of essential oil of Vitex agnus-castus with common antibiotics invitro. Qom Uni. Med. Sci. J. 2015, 9, 12-19.

67. Katiraee, F.; Mahmoudi, R.; Tahapour, K.; Hamidian, G.; Emami, S.J. Biological properties of Vitex agnus-castus essential oil (Phytochemical component, antioxidant and antifungal activity). Biotechnol. Health Sci. 2015, 2, e26797. [CrossRef]

68. Yilar, M.; Bayan, Y.; Onaran, A. Chemical composition and antifungal effects of Vitex agnus-castus L. and Myrtus communis L. Plants. Not. Bot. Horti Agrobot. Cluj-Napoca 2016, 44, 466-471. [CrossRef]

69. Stojković, D.; Soković, M.; Glamočlija, J.; Džamić, A.; Ćirić, A.; Ristić, M.; Grubišić, D. Chemical composition and antimicrobial activity of Vitex agnus-castus L. fruits and leaves essential oils. Food Chem. 2011, 128, 1017-1022. [CrossRef]

70. Arokiyaraj, S.; Perinbam, K.; Agastian, P.; Kumar, R.M. Phytochemical analysis and antibacterial activity of Vitex agnus-castus. Int. J. Green Pharm. (IJGP) 2009, 3, 162-164. [CrossRef] 
71. Goncalves, R.; Ayres, V.F.; Carvalho, C.E.; Souza, M.G.; Guimaraes, A.C.; Correa, G.M.; Martins, C.H.; Takeara, R.; Silva, E.O.; Crotti, A.E. Chemical composition and antibacterial activity of the essential oil of Vitex agnus-castus L.(Lamiaceae). An. Acad. Bras. Ciências 2017, 89, 2825-2832. [CrossRef]

72. Keikha, N.; Shafaghat, M.; Mousavia, S.M.; Moudi, M.; Keshavarzi, F. Antifungal effects of ethanolic and aqueous extracts of Vitex agnus-castus against vaginal isolates of Candida albicans. Curr. Med. Mycol. 2018, 4, 1. [CrossRef]

73. Asdadi, A.; Hamdouch, A.; Oukacha, A.; Moutaj, R.; Gharby, S.; Harhar, H.; El Hadek, M.; Chebli, B.; Hassani, L.I. Study on chemical analysis, antioxidant and in vitro antifungal activities of essential oil from wild Vitex agnus-castus L. seeds growing in area of Argan Tree of Morocco against clinical strains of Candida responsible for nosocomial infections. J. Mycol. Med. 2015, 25, e118-e127. [CrossRef]

74. Sultan Aslantürk, Ö.; Aşkın Çelik, T. Antioxidant activity and anticancer effect of Vitex agnus-castus L. (Verbenaceae) seed extracts on MCF-7 breast cancer cells. J. Biomol. Struct. 2013, 66, 257-267.

75. Rashed, K.N. Antioxidant activity of different extracts of Vitex agnus-castus (L.) and phytochemical profile. Res. Pharm. 2013, 3, 1-5.

76. Sağlam, H.; Pabuçcuoğlu, A.; Kıvçak, B. Antioxidant activity of Vitex agnus-castus L. extracts. Phytother. Res. 2007, 21, 1059-1060.

77. Maltaş, E.; Uysal, A.; Yildiz, S.; Durak, Y. Evaluation of antioxidant and antimicrobial activity of Vitex agnus-castus L. Fresenius Environ. Bull. 2010, 19, 3094-3099.

78. Dugoua, J.-J.; Seely, D.; Perri, D.; Koren, G.; Mills, E. Safety and efficacy of chastetree (Vitex agnus-castus) during pregnancy and lactation. J. Popul. Ther. Clin. Pharmacol. 2008, 15, 74-79.

79. Ahmad, B.; Azam, S.; Bashir, S.; Adhikari, A.; Choudhary, M.I. Biological activities of a new compound isolated from the aerial parts of Vitex agnus castus L. Afr. J. Biotechnol. 2010, 9, 9063-9069.

80. Choudhary, M.I.; Jalil, S.; Nawaz, S.A.; Khan, K.M.; Tareen, R.B. Antiinflammatory and lipoxygenase inhibitory compounds from vitex agnus-castus. Phytother. Res. 2009, 23, 1336-1339. [CrossRef]

81. Certo, G.; Costa, R.; D'Angelo, V.; Russo, M.; Albergamo, A.; Dugo, G.; Germanò, M.P. Anti-angiogenic activity and phytochemical screening of fruit fractions from Vitex agnus castus. Nat. Prod. Res. 2017, 31, 2850-2856. [CrossRef]

82. Kour, M.; Madom Anantharaya, V.N.; Bhat, K.M.R.; Chakraborti, S.; Kodavanji, B. Effect of Vitex agnus extract on MNU induced mammary tumor of Sprague Dawley rats. J. Young Pharm. 2017, 9, 367. [CrossRef]

83. Khalilzadeh, E.; Saiah, G.V.; Hasannejad, H.; Ghaderi, A.; Ghaderi, S.; Hamidian, G.; Mahmoudi, R.; Eshgi, D.; Zangisheh, M. Antinociceptive effects, acute toxicity and chemical composition of Vitex agnus-castus essential oil. Avicenna J. Phytomedicine 2015, 5, 218.

84. Hamza, A.H.; AlBishri, W.M.; Alfaris, M.H. Effect of Vitex agnus-castus plant extract on polycystic ovary syndrome complications in experimental rat model. Asian Pac. J. Reprod. 2019, 8, 63.

85. Abu-Raghif, A.R.; Sahib, H.B.; Abbas, S.N. Anti-hyperlipidemic effect of Vitex agnus castus Extracts in Mice. Int. J. Pharm. Sci. Rev. Res. 2015, 35, 120-125.

86. Moreno, F.N.; Campos-Shimada, L.B.; Costa, S.C.D.; Garcia, R.F.; Cecchini, A.L.; Natali, M.R.M.; Vitoriano, A.d.S.; Ishii-Iwamoto, E.L.; Salgueiro-Pagadigorria, C.L. Vitex agnus-castus L.(Verbenaceae) improves the liver lipid metabolism and redox state of ovariectomized rats. Evid.-Based Complement. Alternat. Med. 2015, 2015. [CrossRef] [PubMed]

87. Röhrl, J.; Werz, O.; Ammendola, A.; Künstle, G. Vitex agnus-castus dry extract BNO 1095 (Agnucaston ${ }^{\circledR}$ ) inhibits uterine hyper-contractions and inflammation in experimental models for primary dysmenorrhea. Clin. Phytoscience 2017, 2, 1-12.

88. Sahib, H.B.; Al-Zubaidy, A.A.; Hussain, S.M.; Jassim, G.A. The anti angiogenic activity of vitex agnus castus leaves extracts. Int. J. Pharm. Pharm. Sci. 2014, 6, 863-869.

89. Ahangarpour, A.; Najimi, S.A.; Farbood, Y. Effects of Vitex agnus-castus fruit on sex hormones and antioxidant indices in a D-galactose-induced aging female mouse model. J. Chin. Med. Assoc. 2016, 79, 589-596. [CrossRef]

90. Saberi, M.; Rezvanizadeh, A.; Bakhtiarian, A. The antiepileptic activity of Vitex agnus castus extract on amygdala kindled seizures in male rats. Neurosci. Lett. 2008, 441, 193-196. [CrossRef] [PubMed]

91. Sehmisch, S.; Boeckhoff, J.; Wille, J.; Seidlova-Wuttke, D.; Rack, T.; Tezval, M.; Wuttke, W.; Stuermer, K.; Stuermer, E. Vitex agnus castus as prophylaxis for osteopenia after orchidectomy in rats compared with estradiol and testosterone supplementation. Phytother. Res. 2009, 23, 851-858. [CrossRef] 
92. Chhabra, G.; Kulkarni, S. Evaluation of anti-inflammatory activity of Vitex agnus castus leaves. Quantitative analysis of flavonoids as possible active constituents. J. Pharmacogn. Phytochem. 2014, 3, 183-189.

93. Deniz, G.Y.; Laloglu, E.; Altun, S.; Yiğit, N.; Gezer, A. Antioxidant and anti-apoptotic effects of vitexilactone on cisplatin-induced nephrotoxicity in rats. Biotech. Histochem. 2020,1-8. [CrossRef]

94. Lee, H.; Jung, K.-H.; Lee, H.; Park, S.; Choi, W.; Bae, H. Casticin, an active compound isolated from Vitex Fructus, ameliorates the cigarette smoke-induced acute lung inflammatory response in a murine model. Int. Immunopharmacol. 2015, 28, 1097-1101. [CrossRef]

95. Ibrahim, A.Y.; El-Newary, S.A.; Youness, E.R.; Ibrahim, A.M.; El Kashak, W.A. Protective and therapeutic effect of Vitex agnus-castus against prostate cancer in rat. J. Appl. Pharm. Sci. 2017, 7, 133-143.

96. Webster, D.E.; He, Y.; Chen, S.-N.; Pauli, G.F.; Farnsworth, N.R.; Wang, Z.J. Opioidergic mechanisms underlying the actions of Vitex agnus-castus L. Biochem. Pharmacol. 2011, 81, 170-177. [CrossRef]

97. Ibrahim, S.R.M.; Ahmed, N.; Almalki, S.; Alharbi, N.; El-Agamy, D.S.; Alahmadi, L.A.; Saubr, M.K.; Elkablawy, M.; Elshafie, R.M.; Mohamed, G.A. Vitex agnus-castus safeguards the lung against lipopolysaccharide-induced toxicity in mice. J. Food Biochem. 2019, 43, e12750. [CrossRef] [PubMed]

98. Allahtavakoli, M.; Honari, N.; Pourabolli, I.; Arababadi, M.K.; Ghafarian, H.; Roohbakhsh, A.; Nadimi, A.E.; Shamsizadeh, A. Vitex agnus castus extract improves learning and memory and increases the transcription of estrogen receptor $\alpha$ in hippocampus of ovariectomized rats. Basic Clin. Neurosci. 2015, 6, 185. [PubMed]

99. Oroojan, A.; Ahangarpour, A.; Khorsandi, L.; Najimi, S. Effects of hydro-alcoholic extract of Vitex agnus-castus fruit on kidney of D-galactose-induced aging model in female mice. Iran. J. Vet. Res. 2016, 17, 203.

100. Alimohamadi, R.; Fatemi, I.; Naderi, S.; Hakimizadeh, E.; Rahmani, M.-R.; Allahtavakoli, M. Protective effects of Vitex agnus-castus in ovariectomy mice following permanent middle cerebral artery occlusion. Iran. J. Basic Med. Sci. 2019, 22, 1097.

101. Csupor, D.; Lantős, T.; Hegyi, P.; Benko, R.; Viola, R.; Gyöngyi, Z.; Csécsei, P.; Tóth, B.; Vasas, A.; Márta, K. Vitex agnus-castus in premenstrual syndrome: A meta-analysis of double-blind randomised controlled trials. Complement. Ther. Med. 2019, 47, 102190. [CrossRef]

102. Cerqueira, R.O.; Frey, B.N.; Leclerc, E.; Brietzke, E. Vitex agnus castus for premenstrual syndrome and premenstrual dysphoric disorder: A systematic review. Arch. Women's. Ment. Health 2017, 20, 713-719. [CrossRef]

103. Seidlova-Wuttke, D.; Wuttke, W. The premenstrual syndrome, premenstrual mastodynia, fibrocystic mastopathy and infertility have often common roots: Effects of extracts of chasteberry (Vitex agnus castus) as a solution. Clin. Phytoscience 2017, 3, 6. [CrossRef]

104. Rafieian-Kopaei, M.; Movahedi, M. Systematic review of premenstrual, postmenstrual and infertility disorders of Vitex agnus castus. Electron. Physician 2017, 9, 3685. [CrossRef]

105. Aksoy, A.N.; Gözükara, I.; Kabil Kucur, S. Evaluation of the efficacy of F ructus agni casti in women with severe primary dysmenorrhea: A prospective comparative D oppler study. J. Obstet. Gynaecol. Res. 2014, 40, 779-784. [CrossRef]

106. Eftekhari, M.H.; Rostami, Z.H.; Emami, M.J.; Tabatabaee, H.R. Effects of "vitex agnus castus" extract and magnesium supplementation, alone and in combination, on osteogenic and angiogenic factors and fracture healing in women with long bone fracture. J. Res. Med. Sci. 2014, 19, 1.

107. Eltbogen, R.; Litschgi, M.; Gasser, U.; Nebel, S.; Zahner, C. Vitex agnus-castus extract (Ze 440) improves symptoms in women with menstrual cycle irregularities. Planta Medica 2014, 80, SL19. [CrossRef]

108. De Franciscis, P.; Colacurci, N.; Riemma, G.; Conte, A.; Pittana, E.; Guida, M.; Schiattarella, A. A nutraceutical approach to menopausal complaints. Medicina 2019, 55, 544. [CrossRef] [PubMed]

109. Naseri, R.; Farnia, V.; Yazdchi, K.; Alikhani, M.; Basanj, B.; Salemi, S. Comparison of Vitex agnus-castus Extracts with Placebo in Reducing Menopausal Symptoms: A Randomized Double-Blind Study. J. Korean Acad. Fam. Med. 2019, 40, 362-367. [CrossRef] [PubMed]

110. Greene, J. Methods for assessing climacteric symptoms. J. Br. Menopause Soc. 1999, 5, 173-176. [CrossRef]

111. Yavarikia, P.; Shahnazi, M.; Mirzaie, S.H.; Javadzadeh, Y.; Lutfi, R. Comparing the effect of mefenamic acid and vitex agnus on intrauterine device induced bleeding. J. Caring Sci. 2013, 2, 245.

112. Higham, J.M.; O'brien, P.; Shaw, R. Assessment of menstrual blood loss using a pictorial chart. BJOG 1990, 97, 734-739. [CrossRef] 
113. He, Z.; Chen, R.; Zhou, Y.; Geng, L.; Zhang, Z.; Chen, S.; Yao, Y.; Lu, J.; Lin, S. Treatment for premenstrual syndrome with Vitex agnus castus: A prospective, randomized, multi-center placebo controlled study in China. Maturitas 2009, 63, 99-103. [CrossRef]

114. Ma, L.; Lin, S.; Chen, R.; Wang, X. Treatment of moderate to severe premenstrual syndrome with Vitex agnus castus (BNO 1095) in Chinese women. Gynecol. Endocrinol. 2010, 26, 612-616. [CrossRef]

115. Zamani, M.; Neghab, N.; Torabian, S. Therapeutic effect of Vitex agnus castus in patients with premenstrual syndrome. Acta Med. Iran. 2012, 50, 101-106. [PubMed]

116. Shahnazi, M.; Khalili, A.F.; Hamdi, K.; Ghahremaninasab, P. The effects of combined low-dose oral contraceptives and Vitex agnus on the improvement of clinical and paraclinical parameters of polycystic ovarian syndrome: A triple-blind, randomized, controlled clinical trial. Iran. Red Crescent Med. J. 2016, 18. [CrossRef]

117. Molaie, M.; Darvishi, B.; Jafari Azar, Z.; Shirazi, M.; Amin, G.; Afshar, S. Effects of a combination of Nigella sativa and Vitex agnus-castus with citalopram on healthy menopausal women with hot flashes: Results from a subpopulation analysis. Gynecol. Endocrinol. 2019, 35, 58-61. [CrossRef] [PubMed]

118. De Franciscis, P.; Grauso, F.; Luisi, A.; Schettino, M.T.; Torella, M.; Colacurci, N. Adding Agnus Castus and magnolia to soy isoflavones relieves sleep disturbances besides postmenopausal vasomotor symptoms-long term safety and effectiveness. Nutrients 2017, 9, 129. [CrossRef]

119. Aydin, İ.; Baltaci, D.; Trkyilmaz, S. Comparison of Vitex Agnus Castus with Meloxicam and Placebo in Treatment of Patients with Cyclical Mastalgia. Duzce Med. J. 2012, 14, 1-5.

120. Momoeda, M.; Sasaki, H.; Tagashira, E.; Ogishima, M.; Takano, Y.; Ochiai, K. Efficacy and safety of Vitex agnus-castus extract for treatment of premenstrual syndrome in Japanese patients: A prospective, open-label study. Adv. Ther. 2014, 31, 362-373. [CrossRef] [PubMed]

121. Ambrosini, A.; Di Lorenzo, C.; Coppola, G.; Pierelli, F. Use of Vitex agnus-castus in migrainous women with premenstrual syndrome: An open-label clinical observation. Acta Neurol. Belg. 2013, 113, 25-29. [CrossRef]

122. Schellenberg, R.; Zimmermann, C.; Drewe, J.; Hoexter, G.; Zahner, C. Dose-dependent efficacy of the Vitex agnus castus extract Ze 440 in patients suffering from premenstrual syndrome. Phytomedicine 2012, 19, 1325-1331. [CrossRef]

123. Abbaspoor, Z.; Hajikhani, N.A.; Afshari, P. Effect of Vitex agnus-castus on menopausal early symptoms in postmenopausal women: A randomized, double blind, placebo-controlled study. J. Adv. Med. Med. Res. 2011, 1, 132-140. [CrossRef]

124. van Die, M.D.; Bone, K.M.; Burger, H.G.; Reece, J.E.; Teede, H.J. Effects of a combination of Hypericum perforatum and Vitex agnus-castus on PMS-like symptoms in late-perimenopausal women: Findings from a subpopulation analysis. J. Altern. Complement. Med. 2009, 15, 1045-1048. [CrossRef]

125. Hossein-Rashidi, B.; Nemati, M. Effects of Vitex agnus-castus extract on the secretory function of pituitary-gonadal axis and pregnancy rate in patients with premature ovarian aging (POA). J. Herb. Med. 2017, 10, 24-30. [CrossRef]

126. Merz, P.-G.; Gorkow, C.; Schrödter, A.; Rietbrock, S.; Sieder, C.; Loew, D.; Dericks-Tan, J.; Taubert, H. The effects of a special Agnus castus extract (BP1095E1) on prolactin secretion in healthy male subjects. Exp. Clin. Endocrinol. Diabetes 1996, 104, 447-453. [CrossRef] [PubMed]

127. Owolabi, M.A.; Abass, M.M.; Emeka, P.M.; Jaja, S.I.; Nnoli, M.; Dosa, B.O. Biochemical and histologic changes in rats after prolonged administration of the crude aqueous extract of the leaves of Vitex grandifolia. Pharmacogn. Res. 2010, 2, 273-278. [CrossRef]

(C) 2020 by the authors. Licensee MDPI, Basel, Switzerland. This article is an open access article distributed under the terms and conditions of the Creative Commons Attribution (CC BY) license (http://creativecommons.org/licenses/by/4.0/). 